\title{
Influence of Drought and Wounding Stress on Soluble Phenols and Proteins in Potato Tubers
}

\author{
Christina B. Wegener ${ }^{1}$, Gisela Jansen ${ }^{1} \&$ Hans-Ulrich Jürgens ${ }^{1}$ \\ ${ }^{1}$ Julius Kühn-Institute, Federal Research Centre for Cultivated Plants, Institute for Resistance Research and \\ Stress Tolerance, Rudolf-Schick-Platz 3, D-18190 Sanitz, Germany \\ Correspondence: Christina B. Wegener, Julius-Kühn Institute, Rudolf Schick-Platz 3, D-18190 Sanitz, Germany. \\ E-mail: christina.wegener@jki.bund.de
}

\author{
Received: February 8, 2014 Accepted: April 30, 2014 Online Published: May 9, 2014 \\ doi:10.5539/sar.v3n3p1 URL: http://dx.doi.org/10.5539/sar.v3n3p1
}

\begin{abstract}
Potato is a valuable source for phytochemicals like vitamins, minerals, plant phenols, amino acids and proteins. However, environmental stress may affect the level of all these components. In this study, two purple breeding clones and one yellow fleshed cultivar (cv.) were assessed in their response to drought and wounding stress in two consecutive years. The plants were grown in the greenhouse under control (sufficient water supply) and with drought stress conditions. After harvest the tubers were analyzed for the content of soluble phenols and proteins in fresh tissue and after wounding. In addition, free amino acids (AAS) and activity of lipid acyl hydrolases (LAH) were assayed in control and drought stressed tubers. The results revealed significant differences in soluble phenols and proteins between genotypes, and that drought stress significantly increased the level of soluble proteins $(\mathrm{P}<0.0001)$ and LAH activity $(\mathrm{P}<0.001)$, but had no significant effect on the concentration of phenols. Moreover, total amounts of free AAS were higher in the drought stress variant. Wounding stress caused a significant increase of soluble phenols in cv. Agave. But, this was less prominent in purple clones which in general had higher contents of phenols. Proteins were also enhanced as a result of wounding, although, the effect of wounding stress on their level was smaller than that of drought stress.
\end{abstract}

Keywords: abiotic stress, stress responses, tuber quality, lipid acyl hydrolase, amino acids

\section{Introduction}

With its high nutritional value and the high level of human consumption potato (Solanum tuberosum L.) is one of the most important crops for human nutrition and of special interest to combat hunger in the world (Cahskan \& Struik, 2010). In the last two decades potato production increased rapidly in developing or underdeveloped countries with a warmer climate in Asia, Africa and Latin America (Cahskan et al., 2010). Potato tubers are rich in starch, proteins, minerals and vitamins (Buckenhüskes, 2005; Jansen et al., 2001) and contain valuable secondary metabolites such as plant phenols (Friedman, 1997) including hydroxycinnamates, e.g. $p$-coumaric, caffeic, chlorogenic, sinapic and ferulic acid (precursor for lignin) and flavonoids, e.g. anthocyanindins like petunidin, peonidin, malvidin etc. (Brown et al., 2003) synthesized all via the phenylpropanoid metabolism (Crozier et al., 2006). Phenolic compounds play a key role in resistance expression of plants (Nicholson \& Hammerschmidt, 1992) and act as radical scavengers (Grace, 2005) reducing toxic effects of oxidative stress on metabolism and cells (Noctor \& Foyer, 1998). Plant phenols are inducible by environmental stresses (Dixon \& Paiva, 1995) and involved in acclimation of plants to non-optimal conditions (Grace, 2005). After wheat, rice and maize the potato is the fourth most important source of protein for human consumption in the world (De Romana et al., 1981). Its tuber protein has a high nutritional and biological quality (Desborough et al., 1981; Kapoor et al., 1975) and is seen to be superior to proteins of other crops like cereals and legumes (Bohac, 1991). Also several proteins are induced by diverse types of stress (Mehta et al., 1991) and similarly as phenols generate antiradical activities, i.e. health promoting effects in humans when consumed (Grace, 2005; Liu et al., 2003).

In nature, plants face a wide range of threats during growth, and abiotic stress will become a growing risk in the near future, especially in the course of climate changes. In this respect, drought is one of the most important abiotic stress factors limiting crop production worldwide (Passioura, 2007). Today about 700 million people around the world suffer from water shortage. It is expected that two-third of the world population will be living under drought stress conditions by 2025 and that water scarcity will threaten the natural resources (Anonymus, 2005). Plants have 
the potential to adapt to such stressful conditions to a certain extent. For example, potato tubers respond to environmental stresses by alterations of macromolecular synthesis, e.g. by synthesizing a set of proteins (Vayda \& Schaeffer, 1988). Significantly higher protein contents were also found in chickpea plants that were imposed to drought at the vegetative stage (Mafakheri et al., 2011), and new protein bands were discovered in drought stressed plants of different Vitex species (John et al., 2011). Proteome studies revealed that 10 of 12 proteins tested in this frame were increased in rice leaf sheath after drought stress (Ali \& Komatsu, 2006), and dehydrin-like proteins could be detected in roots and leaves of drought stressed maize plants (Mohammadkhani \& Heidari, 2008). In addition, late embryogenesis abundant (LEA) proteins are known to contribute in protecting plants to diverse types of stress, above all drought stress (Galau et al., 1993; Hong-Bo et al., 2005). LEA proteins are extremely hydrophilic and proposed to prevent the formation of damaging protein aggregates during drying, and to protect membranes and other proteins (Goyal et al., 2005; Hand et al., 2011). However, all these stress responses may be associated with alterations in the biochemical composition resulting in differences concerning physiological traits and with it in resistance and quality properties of tubers. Hence, it is important to get a better knowledge on stress responses and metabolic changes in plant tissue and their impact on the quality.

In this study, three potato genotypes including one yellow fleshed cultivar and two purple breeding clones were assessed for their reaction to drought and wounding stress representing two of the major abiotic stress factors in nature. Results of a first study on changes of the antioxidant capacity were published already (Wegener \& Jansen, 2013). In addition to this, the aim of the present work was to get information on the influence of drought and wounding stress on soluble phenols and proteins accumulated in tuber tissue. Moreover, the effects of drought stress on the level of free amino acids (AAS) and the activity of lipid acyl hydrolases (LAH) associated with the glycoprotein patatin comprising about $30 \%$ of the soluble proteins in potato tubers (Moreau \& Nagahashi, 1987) was investigated. LAH present in protein extracts from potato tubers are lipolytic enzymes with different substrate preference (Anderson et al., 2002; Andrews et al., 1988; Hasson \& Laties, 1976) that are capable of hydrolysing monoacylglycerols (MAG), phospholipids and galactolipids to form fatty acids and fatty acid hydroperoxides (Galliard, 1971), but can also be used under certain conditions to synthesize MAG (Macrae et al., 1998). Changes in the composition of membrane lipids may contribute to protect cell membranes under stress conditions (Gigon et al., 2004).

\section{Material and Methods}

The plants of the three genotypes were grown in a glasshouse (i) with sufficient water supply (= control plants) and (ii) with severe drought stress conditions (= drought stressed plants) in 2010 and 2011. After harvest in September of each test year, the tuber yield was determined for each genotype and variant with results published elsewhere (Wegener \& Jansen, 2013).

\subsection{Plant Material}

The study was carried out on three potato genotypes including one yellow fleshed cv. Agave (early season) and two purple breeding clones St 89403 and St 3792 (early-mid season, both), all from the breeding company NORIKA, Groß Lüsewitz, Germany. Agave is a cultivar with optimal yield and quality properties and two purple clones were chosen, because they contain high amounts of anthocyanins. Each randomized experimental set for the control and the drought stress variant was performed with four replications, comprising four plants per genotype and replication. In vitro plants were used for planting. The plants were grown in pots with $130 \mathrm{~mm}$ in diameter filled with a turf (95\%)-sand (5\%) mixture from April to September in the years 2010 and 2011 in a greenhouse. The mean temperature $\left({ }^{\circ} \mathrm{C}\right)$ during the growing seasons in 2010/2011 was as followed: May, 9.7/12.8; June, 15.1/16.1; July, 20.6/17.0; August, 17.1 both years; September, 12.8/14.7. Fertilizer, insecticides, fungicides and all other agronomic measures were conducted according to local practice, and drought stress was applied as detailed below. After harvest, the tubers were stored in a controlled environment at $5{ }^{\circ} \mathrm{C}$ until the tissue samples were prepared for the assay of phenols, proteins, LAH activity and free AAS. All analyses started in November and were finished in December of each test year.

\subsection{Application of Drought and Wounding Stress}

Control plants were watered daily during the whole growing period (=sufficient water supply). Plants involved in drought stress experiments were watered daily up to seven weeks after planting (= start of tuber initiation - growth stage code 40400 ) (Meier, 1997), before the water supply was completely stopped during a time-span of six days. After that time, each plant received only $50 \mathrm{ml}$ of water per day. From the middle to August until the end of experiments the amount of water was further reduced up to $30 \mathrm{ml}$ daily per plant. In 2010, the weather was warm und sunny during the main growing period, especially in July. Therefore, only one drought period was applied in that year. In 2011, the weather was cool and cloudy, so that a second drought period of six days was inserted 11 
weeks after planting. In addition to drought stress, wounding stress was applied as described in paragraph 2.3., in context with phenol and protein analyses. Both types of stress were applied as it can be expected under production conditions in agriculture.

\subsection{Assay of Soluble Phenols and Proteins}

Analyses of soluble phenols and proteins were carried out for fresh and wounded tuber tissue in 2010 and 2011 as detailed in Wegener and Jansen, 2010. For the preparation of tissue extracts ten medium sized tubers were taken from each genotype and replication as an average sample. The tubers were washed, air-dried and then cut into halves by means of a knife (= mechanical wounding procedure), and using a cork borer of $5 \mathrm{~mm}$ in diameter two cylinders were excised from the outer region of each half and each tuber. In order to study the effect of wounding stress on the level of soluble phenols and proteins two cylinder samples were taken per genotype and assay: the first one was excised from (i) fresh tissue and a second was cut (ii) $24 \mathrm{~h}$ after wounding of the tubers. Before cutting the second tissue sample, the tuber halves of each experimental set were stored for $24 \mathrm{~h}$ at $20^{\circ} \mathrm{C}$ with the wound-surface upward on moist filter papers placed in a plastic box covered with a lid. This was performed in order to study the effect of wound stress within a period of $24 \mathrm{~h}$.

For the assay of phenols, a $1 \mathrm{~mm}$ thick slice was excised from the upper wound region of each cylinder. The slices were pooled, and $1 \mathrm{~g}$ of the slices was ground under liquid nitrogen before the homogenate was suspended in $4 \mathrm{ml}$ of methanol (Roth, Karlsruhe, Germany). The suspension was stirred slightly and after $1 \mathrm{~h}$ centrifuged at $6000 \times \mathrm{g}$ for $10 \mathrm{~min}$ at $4{ }^{\circ} \mathrm{C}$. The supernatant was removed and the plant material re-extracted. The total amount of phenols present in the combined extracts was assayed using Folin-Ciocalteu reagent (Sigma-Aldrich, Taufkirchen, Germany) according to Cahill and McComb (1992). The absorbance was measured at $725 \mathrm{~nm}$ on a UV spectrophotometer (Kontron Instruments, Neufahrn, Germany). Standards were prepared from $p$-coumaric acid (Sigma-Aldrich, Taufkirchen, Germany), and total amounts of soluble phenols (= coumaric acid equivalent) were expressed in grams per kilogram of fresh weight ( $\mathrm{fw}$ ).

For the assay of soluble proteins, the slices cut from the cylinders as detailed above were pooled and $3 \mathrm{~g}$ of the slices were ground under liquid nitrogen before the thawed homogenate was centrifuged at $15000 \times g$ for 10 min at $4{ }^{\circ} \mathrm{C}$. Amounts of proteins were assayed in the supernatant (= cell sap fraction) by means of a Bradford assay using a Roti ${ }^{\mathrm{R}}$-Quant reagent (Roth, Karlsruhe, Germany) according to the manufacturer recommendations. The absorbance was measured at $595 \mathrm{~nm}$ on a UV spectrophotometer (Kontron Instruments). Standards were prepared from bovine serum albumin (Sigma-Aldrich, Taufkirchen, Germany), and total amounts of soluble proteins were calculated as milligrams per millilitre of protein extract. Extract preparations and all analyses of phenols and proteins were carried out in triplicate with standard deviation $(\mathrm{SD}) \leq 5 \%$.

\subsection{Assay of Lipid Acyl Hydrolase Activity}

Analyses of LAH in 2010 and 2011 were carried out for control and drought stressed tubers. As an average sample, five medium sized tubers were randomly taken from each genotype and replication before the tubers from two replications of each genotype were pooled into one sample. The tubers were cut into halves using a knife, and a $2 \mathrm{~mm}$ thick tissue section was excised from each tuber half before $25 \mathrm{~g}$ of the slices were weight, dried in a freeze drying unit type Alpha 1-4 LD plus (Christ, Osterode, Germany) and then ground in a laboratory mill SM3 equipped with a fine sieve (Brabender, Duisburg, Germany). The lyophilized tissue powder was used for the analyses of LAH as detailed below.

The assay of LAH activity was carried out according to Bohac (1991) with several modifications. $100 \mathrm{mg}$ of

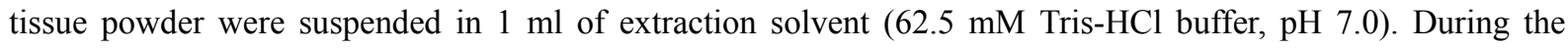
extraction of proteins for $3 \mathrm{~h}$ at $4{ }^{\circ} \mathrm{C}$ the mixture was occasionally vortexed and then centrifuged at $12000 \times g$ for $3 \mathrm{~min}$. The supernatant was removed, stored at $-18{ }^{\circ} \mathrm{C}$ and thawed short before measurement of enzyme activity at $410 \mathrm{~nm}$ on a UV spectrophotometer (Kontron Instruments) using the kinetic programme at $20^{\circ} \mathrm{C}$. The reaction mixture consisted of $800 \mu \mathrm{l}$ of sample buffer ( $10 \mathrm{mM}$ Tris-HCl, $\mathrm{pH} 7.5), 100 \mu \mathrm{l}$ of substrate solution containing $10 \mathrm{mM}$ Tris- $\mathrm{HCl}$ (pH 7.5), 1\% Triton X-100 (Amersham Bioscience, Uppsala, Sweden), 0.017\% SDS (Pharmacia Biotech, Uppsala, Sweden) and $530 \mu \mathrm{M}$ p-nitrophenyl-laurate (PNP) (Sigma-Aldrich) and was started by adding $100 \mu \mathrm{l}$ of protein extract diluted in sample buffer. One enzyme unit was defined as the increase in absorbance units per minute and milligram freeze-dried matter. Analyses of LAH were performed in triplicate with $\mathrm{SD} \leq 5 \%$.

\subsection{Assay of Free Amino Acids}

Analyses of AAS were performed for control and drought stressed tubers grown in 2010. In order to prepare the tissue extracts, twenty medium sized tubers ( $=5$ tubers per replication) were randomly taken as an average sample 
for each genotype. The tubers were cut into slices and $20 \mathrm{~g}$ of these slices were homogenized in $50 \mathrm{ml}$ of $96 \%$ ethanol at $15000 \mathrm{rpm}$ for $30 \mathrm{sec}$, using a knife homogenizer HO4AP (Bühler, Hechingen, Germany). The homogenate was suspended in a solution containing $95 \mathrm{ml}$ of $96 \%$ ethanol and $40 \mathrm{ml}$ deionized water, then transferred into a $250 \mathrm{ml}$ flask and mixed vigorously. Afterwards, a $50 \mathrm{ml}$ sample was taken from this suspension, stored at $-18^{\circ} \mathrm{C}$ and thawed shortly before the analyses of free AAS.

Free amino acids were measured following the methods detailed by Cohen \& Michaud (1993) adapted to a Luna C18 (2) bonded silica column (Phenomenex, Aschaffenburg, Germany) according to Hernández-Orte et al. (2003). Sodium tetraborate decahydrate, sodium azide, glacial acetic acid and $96 \%$ ethanol were obtained from Merck (Darmstadt, Gemany), 6-aminoquinolyl-N-hydroxysuccinimidyl carbamate (AQC) was synthesized according to Cohen and Michaud (1993) and all other chemicals used in the analyses were from Sigma-Aldrich.

HPLC assay was carried out in an Agilent 1100 series liquid chromatograph system (Agilent Technologies, Waldbronn, Germany) with a fluorescence detector (EX, $250 \mathrm{~nm}$; EM, $400 \mathrm{~nm}$ ). The separation of AAS was performed on a Luna C18 (2) column $(150 \times 2.0 \mathrm{~mm} ; 3.0 \mu \mathrm{m})$, equipped with an inline filter $(2.1 \mathrm{~mm} ; 0.2 \mu \mathrm{m})$, at a flow rate of $0.25 \mathrm{ml} \mathrm{min}^{-1}$. The injection volume was $1 \mu 1$, and the column temperature was maintained at $30^{\circ} \mathrm{C}$. Quantities of free AAS were expressed in milligrams per $100 \mathrm{~g}$ of fresh weight (fw), and the analyses were carried out in duplicate with $\mathrm{SD} \leq 5 \%$.

\subsection{Statistical Analyses}

Standard statistical methods were used for the data analyses. The results in the tables are presented as mean values $\pm \mathrm{SD}$ (standard deviation). To assess effects of drought stress on soluble phenols, proteins and LAH a generalized linear model for the analysis of variance was applied, using the SAS 9.2 statistical package (PROC GLM, Tukey-test, SAS Institute Inc., Cary, NC, USA). The latter was also used in order to study the effect of wounding stress, the year and the genotype on all these parameters. $\mathrm{P} \leq 0.05$ was considered statistically significant. Correlations (Pearson) between individual parameters were calculated using the SAS 9.2 statistical package (Procedure CORR). $\mathrm{P} \leq 0.05$ was regarded to be statistically significant.

\section{Results and Discussion}

It should be mentioned at the beginning, that the tuber yield of all three potato genotypes was significantly diminished ( $\mathrm{P}<0.05$, all) by severe drought stress in 2010 and 2011. The decrease of tuber yield amounted on average 44\% in 2010 and 34\% in 2011 (Wegener \& Jansen, 2013). This strong reduction in tuber yield indicates that drought stress was successfully applied thus enabling the study of its effects on phenols, proteins, LAH and free amino acids. In addition the amino acid proline (pro) seen as a metabolic marker for drought stress (Munawarti et al., 2013) was enhanced in drought stressed tubers as discussed below, in paragraph 3.3. Drought stress was applied as it can regularly happen. But, this is only one of many scenarios that plants can experience in nature.

\subsection{The Effect of Drought Stress on Soluble Phenols}

Differences between the genotypes: In both years, the three potato genotypes varied in contents of soluble phenols (Table 1). The purple clone St 89403 revealed the highest amount of phenols in all tuber variants in each year, while cv. Agave generally had the lowest phenol contents. 
Table 1. Amounts of soluble phenols present in fresh tissue and $24 \mathrm{~h}$ after wounding of control and drought stressed tubers grown in 2010 and $2011($ Mean \pm SD)

\begin{tabular}{|c|c|c|c|c|c|}
\hline \multirow{3}{*}{ Years } & \multirow{3}{*}{ Genotypes } & \multicolumn{4}{|c|}{ Soluble phenols $\left(\mathrm{g} \mathrm{kg}^{-1}\right)$} \\
\hline & & \multicolumn{2}{|l|}{ Control } & \multicolumn{2}{|l|}{ Drought stress } \\
\hline & & Fresh & Wounded & Fresh & Wounded \\
\hline \multirow{4}{*}{2010} & St 89403 & $2.93 \pm 0.18 \mathrm{a}^{\dagger}$ & $2.57 \pm 0.18 \mathrm{a}^{\dagger}$ & $2.92 \pm 0.25 \mathrm{a}$ & $2.82 \pm 0.23 \mathrm{a}$ \\
\hline & St 3792 & $1.77 \pm 0.11 \mathrm{~b}$ & $1.64 \pm 0.27 b$ & $2.00 \pm 0.27 b$ & $1.87 \pm 0.35 b$ \\
\hline & Agave & $0.62 \pm 0.08 \mathrm{c}^{\dagger \dagger \dagger}$ & $1.04 \pm 0.05 \mathrm{c}^{\dagger \dagger}$ & $0.65 \pm 0.04 \mathrm{c}^{\dagger \dagger \dagger}$ & $1.01 \pm 0.07 \mathrm{c}^{\dagger \dagger \dagger}$ \\
\hline & Average & $1.77 \pm 1.00$ & $1.75 \pm 0.68$ & $1.86 \pm 0.99$ & $1.90 \pm 0.80$ \\
\hline \multirow{4}{*}{2011} & St 89403 & $3.12 \pm 0.24 \mathrm{a}^{* \dagger}$ & $2.79 \pm 0.22 \mathrm{a}^{* \dagger}$ & $2.62 \pm 0.14 \mathrm{a}^{*}$ & $2.47 \pm 0.11 \mathrm{a}^{*}$ \\
\hline & St 3792 & $2.26 \pm 0.04 \mathrm{~b}^{* * \dagger \dagger}$ & $2.08 \pm 0.05 b^{\dagger \dagger}$ & $1.97 \pm 0.10 \mathrm{~b}^{* *}$ & $2.14 \pm 0.14 b$ \\
\hline & Agave & $0.62 \pm 0.02 \mathrm{c}^{\dagger \dagger \dagger}$ & $0.91 \pm 0.02 \mathrm{c}^{\dagger \dagger \dagger}$ & $0.64 \pm 0.05 \mathrm{c}^{\dagger \dagger \dagger}$ & $1.07 \pm 0.04 \mathrm{c}^{\dagger \dagger \dagger}$ \\
\hline & Average & $2.00 \pm 1.09$ & $1.93 \pm 0.82$ & $1.74 \pm 0.87$ & $1.89 \pm 0.63$ \\
\hline
\end{tabular}

a,b,c Genotype means followed by different letters within the same column differ significantly at $\mathrm{P} \leq 0.05$; Significance of the difference in phenols between control and drought stressed tubers at $* \mathrm{P} \leq 0.05$ and $* * \mathrm{P} \leq 0.01$, and between fresh and wounded tubers at ${ }^{\dagger} \mathrm{P} \leq 0.05,{ }^{\dagger} \mathrm{P} \leq 0.01$ and ${ }^{\dagger \dagger} \mathrm{P} \leq 0.0001$. Significance of the difference between the years is described in detail in paragraph 3 .

In 2010 and 2011, all differences in phenols between the genotypes were statistically significant as represented with different letters in the same column within Table 1.

Differences between the variants: In 2010, the differences in soluble phenols between control and drought stressed tubers (fresh and wounded) of the three potato genotypes were all statistically not significant (Table 1). In 2011, St 89403 had significantly $(\mathrm{P}<0.05)$ lower amounts of phenols in fresh and wounded tubers imposed to drought stress than in appropriate control tubers grown with sufficient water supply (Table 1). This was similarly noticed for St 3792, however only within fresh tubers $(\mathrm{P}<0.01)$, and not when its wounded tubers were regarded. The yellow fleshed cv. Agave was less affected by drought stress than the others. In both years the differences in phenols between control and drought stress variants of this cultivar were statistically not significant. These results show that changes in phenols caused by drought stress are dependent on the genotype and the year. In summary, differences in phenols between control and drought stress variants were statistically not significant, i.e. when all genotypes and both years were regarded. These results may demonstrate, that the effect of drought stress on phenols is less evident, as noticed already for anthocyanins (Ac), peroxidases (POD) and the antioxidant capacity (Wegener \& Jansen, 2013). Obviously, phenols as well as Ac and POD are far more involved in plant responses to biotic stress, such as pathogenic attack by microorganisms (Ghanekar et al., 1984) than in drought stress responses. The fact, that phenols were not strongly affected by drought stress can be seen as an advantage, because phenolic compounds contribute to the overall nutritional value of potatoes. However, it remains to be established if this tendency can be transferred to other potato genotypes.

Differences between the years: In the control tubers grown with sufficient water supply, the amounts of soluble phenols were on average higher in 2011 than 2010 (Table 1). The difference between the years was statistically significant $(\mathrm{P}<0.05)$. In 2010, the summer was relatively warm, e.g. in July the mean temperature was higher than in 2011, a fact that could coincide with a higher pathogen pressure. Together with POD enzymes, plant phenols are involved in the formation of lignin and suberin associated both with wound healing and resistance expression (Espelie et al., 1986; Vance et al., 1980). Hence, it is imaginable that a few simple phenolic compounds might be incorporated into lignin and suberin like polymers, probably in response to pathogens and were found to be reduced therefore in 2010. In this frame, it is interesting to mention that in the case of drought stressed tubers the effect of the year on the level of phenols was statistically not significant in summary and within genotypes (Table 
1). Under conditions of drought stress, the role of plant pathogens was obviously less prominent, since the latter also need water for their spread.

\subsection{Effect of Wounding Stress on Soluble Phenols}

Mechanical wounding of the tubers was performed as it can happen in agricultural practice. With it, the results may reflect a real situation. After wounding, the quantity of soluble phenols was notably enhanced in tubers of $\mathrm{cv}$. Agave (up to 67.7\%), a tendency that was observed in both years for control and drought stressed tubers of this cultivar (Table 1). The differences in phenols between fresh and wounded tubers of cv. Agave were all statistically significant $(\mathrm{P}<0.0001$, in control and drought stressed tubers of each year). But, two purple clones with their high basic level of phenols behave different than this yellow fleshed cultivar. In most cases, their phenols were reduced after wounding (Table 1). This could be observed in control and drought stressed tubers of both clones in the year 2010, and again in 2011 for both tuber variants of St 89403 as well as for control tubers of St 3792. The differences in phenols caused by wounding were statistically significant within control tubers of St $89403(\mathrm{P}<0.05$, both years) and St $3792(\mathrm{P}<0.01,2011)$, but they were not significant within drought stressed tubers of both clones. Also in summary, the differences in phenols between fresh and wounded tubers were statistically not significant. These results may demonstrate that the changes in phenols caused by wounding are dependent on the genotype. A similar differentiated wound-induced alteration of phenols has been reported for several cultivated and wild Solanum species (Wegener \& Jansen, 2010). Based on their antimicrobial activity, plant phenols play a key role in pathogen defence (Ghanekar et al., 1984; Lyon \& McGill, 1988; Weber et al., 1996) and as already mentioned they are precursors for lignin and suberin (Espelie et al., 1986; Vance et al., 1980). It is imaginable therefore that in tissue of cv. Agave the phenols raised significantly upon wounding due to its low basis phenol content (Table 1). The two purple clones with their relatively high basis level of phenols did not increase their phenols further. On the contrary, in most cases their phenols were reduced by wounding (Table 1). Probably, the purple clones have started to integrate a few simple phenolics into more complex suberin and lignin related compounds after wounding. This could be a real advantage for purple potatoes, since a rapid suberization and wound healing is most critical in avoiding pathogen infections (Lulai \& Corsini, 1998). In addition, it may be helpful to maintain water, and thus tuber quality during storage.

\subsection{The Effect of Drought Stress on Soluble Proteins, Lipid Acyl Hydrolases and Free Amino Acids}

Differences in proteins between the genotypes: St 89403 displayed the highest amounts of soluble proteins in control and drought stressed tubers among the three genotypes (Table 2). In both years, the yellow fleshed cv. Agave had the lowest content of proteins in fresh and wounded control tubers, while in the case of drought stressed tubers St 3792 ranked on the lowest protein level. Differences in proteins between genotypes were all statistically significant as indicated with different letters within the same column in Table 2, except St 3792 and cv. Agave with their wounded drought stressed tubers tested in 2011.

Differences in proteins between the variants: In both years, all three genotypes contained higher amounts of soluble proteins in drought stressed tubers than in control tubers grown with sufficient water supply (Table 2). The differences in proteins between these two variants were statistically significant within fresh $(2010, \mathrm{P}<0.0001$; $2011, \mathrm{P}<0.001)$ and wounded tubers $(2010, \mathrm{P}<0.05 ; 2011, \mathrm{P}<0.0001)$ of St 89403 , fresh $(2010, \mathrm{P}<0.001 ; 2011$, $\mathrm{P}<0.01)$ and wounded tubers $(2010, \mathrm{P}<0.0001 ; 2011, \mathrm{P}<0.01)$ of cv. Agave and fresh tubers of St $3792(2011$, $\mathrm{P}<0.01)$. In summary, the protein levels were significantly higher in the drought stress variant, a result valid for fresh and wounded tubers tested in 2010 and 2011 ( $\mathrm{P}<0.0001$; each year and variant). This may demonstrate that drought stress clearly induced the soluble proteins in tuber tissue, i.e. a result that concurred with other studies on plant proteins expressed under drought stress conditions (Mafakheri et al., 2011; John et al., 2011). The observed increase in proteins by drought stress can be seen as an advantage with regard to the nutritional and health value of tubers. However, it is important to find out if this tendency can be transferred to other potato genotypes and which proteins are involved in these processes.

Differences in proteins between the years: It should be pointed out that the amounts of soluble proteins measured in fresh and wounded control tubers were on average higher in 2011 than in 2010 (Table 2), a tendency coinciding with those observed for phenols (Table 1) which were also higher in 2011. The differences in proteins between the two years were statistically significant within fresh and wounded control tubers $(\mathrm{P}<0.05$, both). But, they were not significant when the drought stressed tubers of all genotypes were regarded. 
Table 2. Amounts of soluble proteins in extract samples prepared from fresh tissue and $24 \mathrm{~h}$ after wounding of control and drought stressed tubers grown in 2010 and 2011 (Mean \pm SD)

\begin{tabular}{|c|c|c|c|c|c|}
\hline \multirow{3}{*}{ Years } & \multirow{3}{*}{ Genotypes } & \multicolumn{4}{|c|}{ Soluble proteins $\left(\mathrm{mg} \mathrm{ml}^{-1}\right)$} \\
\hline & & \multicolumn{2}{|l|}{ Control } & \multicolumn{2}{|l|}{ Drought stress } \\
\hline & & Fresh & Wounded & Fresh & Wounded \\
\hline \multirow{4}{*}{2010} & St 89403 & $7.60 \pm 1.37 \mathrm{a}^{* * *}$ & $7.90 \pm 1.41 \mathrm{a}^{*}$ & $12.64 \pm 1.22 \mathrm{a}^{* * *}$ & $11.84 \pm 0.31 \mathrm{a}^{*}$ \\
\hline & St 3792 & $4.54 \pm 0.50 \mathrm{~b}$ & $4.83 \pm 0.47 b$ & $4.58 \pm 0.08 \mathrm{c}$ & $4.93 \pm 0.29 \mathrm{c}$ \\
\hline & Agave & $3.46 \pm 0.14 \mathrm{c}^{* *}$ & $4.03 \pm 0.14 \mathrm{c}^{* * *}$ & $7.68 \pm 0.30 b^{* *}$ & $7.41 \pm 0.11 b^{* * *}$ \\
\hline & Average & $5.20 \pm 1.99 * * *$ & $5.59 \pm 1.91 * * *$ & $8.30 \pm 3.53 * * *$ & $8.06 \pm 2.99 * * *$ \\
\hline \multirow{4}{*}{2011} & St 89403 & $8.05 \pm 0.10 \mathrm{a}^{* *}$ & $8.10 \pm 0.26 \mathrm{a}^{* * *}$ & $10.95 \pm 0.48 \mathrm{a}^{* *}$ & $11.50 \pm 0.12 \mathrm{a}^{* * *}$ \\
\hline & St 3792 & $4.83 \pm 0.13 \mathrm{~b}^{* * \dagger}$ & $5.48 \pm 0.38 \mathrm{~b}^{\dagger}$ & $6.00 \pm 0.28 \mathrm{c}^{* *^{\dagger}}$ & $6.30 \pm 0.34 b^{\dagger}$ \\
\hline & Agave & $4.15 \pm 0.33 \mathrm{c}^{* * \dagger \dagger}$ & $4.73 \pm 0.22 \mathrm{c}^{* * \dagger \dagger}$ & $6.45 \pm 0.19 b^{* *}$ & $6.65 \pm 0.59 b^{* *}$ \\
\hline & Average & $5.68 \pm 1.79 * * * \dagger$ & $6.10 \pm 1.53 * * * \dagger$ & $7.80 \pm 2.35^{* * *}$ & $8.15 \pm 2.50^{* * *}$ \\
\hline
\end{tabular}

a,b,c Genotype means followed by different letters in the same column differ significantly at $\mathrm{P} \leq 0.05$; Significance of the difference in proteins between control and drought stressed tubers at $* \mathrm{P} \leq 0.05, * * \mathrm{P} \leq 0.01$ and $* * * \mathrm{P} \leq$ 0.0001 , and between fresh and wounded tubers at ${ }^{\dagger} \mathrm{P} \leq 0.05$ and ${ }^{\dagger \dagger} \mathrm{P} \leq 0.01$. Significance of the difference between the years is described in detail in paragraph 3 .

Protein extracts derived from potato tubers contain patatin, a family of glycoproteins with molecular weights of approximately $40-43 \mathrm{kDa}$ comprising $20-40 \%$ of the total soluble protein in tubers (Racusen \& Foote, 1980). Patatin is seen as a storage protein exhibiting lipid acyl hydrolase (LAH) activity (Anderson et al., 2002; Andrews et al., 1988; Racusen, 1984) and suggested to be associated with plant stress responses (Bárta et al., 2012; De Souza Candido et al., 2011; Strickland et al., 1995). This was the reason why the LAH was studied in this work.

Differences in LAH between the variants: The assay of LAH revealed significantly higher enzyme activity in drought stressed tubers than in control tubers grown with sufficient water supply (Table 3). Elevated LAH activities caused by drought stress were consistently found for all three genotypes in both years. The differences in LAH between control and drought stressed tubers were all statistically significant at $\mathrm{P}<0.05$ within genotypes and years (Table 3, see column \%Increase).

Differences in LAH between the genotypes: The three genotypes differed significantly in their LAH activity as indicated by the different letters within Table 3. St 89403 had the highest LAH level in both tissue variants and also showed the strongest increase of enzyme activity due to drought stress in 2011. This is an important fact, since lipid acyl hydrolases are lipolytic enzymes that are involved in changes of membrane lipids and release fatty acids (Galliard, 1971). Linolenic acid, for example, can serve as precursors for the biosynthesis of jasmonic acid and its derivatives known for their regular function in plant defence and adaptation to stressful conditions (Schaller et al., 2005; Creelman \& Mullet, 1997). Moreover, acyl hydrolases can stimulate the mobilization of lipid reserves to provide sugars that are involved in osmotic adjustment (Creelman \& Mullet, 1997). Thus, in drought stressed Arabidopsis leaves increased lipolytic activity was associated with reduced lipid contents in response to drought (Gigon et al., 2004).

Altogether, these results support the notion that patatin is involved with its LAH in drought stress responses of tubers. In future, it could be interesting to study its specific role. Although, under conditions of wounding stress the tuber patatin was found to be down regulated, i.e. expression of RNA corresponding to patatin was decreased in tubers after wounding (Logemann et al., 1988). This may explain why soluble proteins comprising the glyocoprotein patatin were less strongly affected by wounding stress than by drought stress as discussed below. 
Table 3. Lipid acyl hydrolase activity in control and drought stressed tubers grown in 2010 and 2011 (Mean \pm $\mathrm{SD})$

\begin{tabular}{|c|c|c|c|c|}
\hline \multirow[b]{2}{*}{ Years } & \multirow[b]{2}{*}{ Genotype } & \multicolumn{3}{|c|}{ Lipid acyl hydrolase activity $\left(\mathrm{U} \mathrm{mg}^{-1} \mathrm{~min}^{-1}\right)$} \\
\hline & & Control & Drought stress & $\%$ Increase \\
\hline \multirow{4}{*}{2010} & St 89403 & $1.63 \pm 0.19 \mathrm{a}$ & $2.98 \pm 0.16 \mathrm{a}$ & $82.8^{*}$ \\
\hline & St 3792 & $0.61 \pm 0.08 \mathrm{~b}$ & $0.86 \pm 0.17 \mathrm{~b}$ & $41.0^{*}$ \\
\hline & Agave & $1.04 \pm 0.05 \mathrm{c}$ & $1.95 \pm 0.14 \mathrm{c}$ & $87.5^{*}$ \\
\hline & Average & $1.09 \pm 0.47$ & $1.93 \pm 0.95^{\star}$ & $77.1^{*}$ \\
\hline \multirow{4}{*}{2011} & St 89403 & $1.60 \pm 0.11 \mathrm{a}$ & $3.58 \pm 0.16 \mathrm{a}$ & $123.8^{*}$ \\
\hline & St 3792 & $0.81 \pm 0.05 b$ & $1.16 \pm 0.10 \mathrm{~b}$ & $43.2 *$ \\
\hline & Agave & $1.22 \pm 0.06 \mathrm{c}$ & $2.08 \pm 0.13 \mathrm{c}$ & $70.5^{*}$ \\
\hline & Average & $1.21 \pm 0.36$ & $2.27 \pm 1.10^{\star}$ & $87.6^{*}$ \\
\hline All years & Average & $1.15 \pm 0.40$ & $2.10 \pm 1.00$ & $82.6^{* *}$ \\
\hline
\end{tabular}

a,b,c Genotype means followed by different letters within the same column differ significantly at $\mathrm{P} \leq 0.05$. The difference between the years was significant at ${ }^{\star} \mathrm{P} \leq 0.01$. Significance of the difference in LAH between control and drought stressed tuber at $* \mathrm{P} \leq 0.05$ and $* * \mathrm{P} \leq 0.01$.

Amino acid assay: About $49 \%$ of total amino acids present in tuber tissue are non-proteinogenic, free amino acids (De Romana et al., 1981). Besides plant proteins, the latter may also play a role in drought stress responses of tubers. Above all proline is known to protect plants against low water potentials and/or drying and is seen as a stress-related signal. For example, changes in proline became significant in Saccharum spontaneum (Munawarti et al., 2013) and poplar when drought progressed (Yang \& Miao, 2010), and proline was increased in maize (Mohammadkhani \& Heidari, 2008) and in tomato root, stem and leaf as a result of drought stress (Ghorbanli et al., 2011), a tendency that was similarly noticed in drought stressed potato plants (Farhad et al., 2011). In agreement with these findings, all potato genotypes tested in this work had higher concentrations of proline in drought stressed tubers than in control tubers grown with sufficient water supply (Table 4). St 89403 displayed the strongest increase of pro (5.8-fold) due to drought stress. This may be additional evidence, besides the strong yield reduction (Wegener \& Jansen, 2013), that the drought stress was successfully applied in this work and may again underline the role of proline in drought stress responses of tuber tissue.

Moreover, it is worth to mention that also total amounts of free AAS were elevated in drought stressed tubers of all genotypes (St 89403, $+42.5 \%$; St 3792, $+61.2 \%$; Agave, $+11.9 \%$ ), and many of the 18 amino acids tested in this frame, i.e. 13 in St 89403, 17 in St 3792 and 11 in cv. Agave, were on a higher level in drought stressed tubers than in control tubers (Table 4). Above all, St 3792 showed strong enhancement of AAS due to drought stress. Besides proline, especially asparagine (asn) was increased upon drought in all genotypes, i.e. asn was elevated by $81.5 \%$ (St 89403), 75.7\% (St 3792) and 42.6\% (cv.Agave), respectively. This corresponds with other studies on AAS, e.g. in Brassica napus leaves most of the amino acids showed an increase (up to 5.9-fold) under drought stress (Good \& Zaplachinski, 1994) and also in leaves of Sporobolus stapfianus the AAS were enhanced by desiccation stress (Martinelli et al., 2007). These results were not surprising, since amino acids are known to function as osmolytes often used by water stressed organisms to maintain the cell volume and to stabilize proteins and other macromolecules (Yancey, 2001). Of the three genotypes, the yellow fleshed cv. Agave ranked on the highest level in total amounts of free AAS in control and drought stressed tubers, followed by St 3792 and St 89403 (Table 4). Agave differed significantly in this respect from St $3792(\mathrm{P}<0.01)$ and St $89403(\mathrm{P}<0.05)$, however, this was only found for control and not for drought stressed tubers of this cultivar. The two purple clones, again, did not differ significantly in their AAS levels. However, it was interesting that the ranking of genotypes with regard to tuber yield under drought stress (Wegener \& Jansen, 2013) correlated with their ranking in total amounts of free 
AAS in drought stressed tubers (Table 4). It is imaginable thus that the whole free amino acids have contributed to adapt to drought during growth. It should be mentioned, that similarly enhanced AAS contents were found in other potato genotypes grown under drought stress conditions (unpublished results).

Table 4. Amounts of free amino acids (AAS) in control and drought stressed tubers grown in 2010

\begin{tabular}{|c|c|c|c|c|c|c|}
\hline \multirow{2}{*}{$\begin{array}{l}\text { Amino acid } \\
\left(\mathrm{mg} 100 \mathrm{~g}^{-1}\right)\end{array}$} & \multicolumn{2}{|l|}{ St 89403} & \multicolumn{2}{|l|}{ St 3792} & \multicolumn{2}{|l|}{ Agave } \\
\hline & Control & Drought & Control & Drought & Control & Drought \\
\hline Alanine & 7.62 & 7.11 & 5.45 & 6.53 & 9.47 & 9.82 \\
\hline Arginine & 10.68 & 14.32 & 14.09 & 27.84 & 23.04 & 23.96 \\
\hline Asparagine & 92.11 & 167.13 & 183.98 & 323.22 & 227.50 & 324.44 \\
\hline Aspartic acid & 17.66 & 18.36 & 10.97 & 17.38 & 22.75 & 24.69 \\
\hline Glutamine & 42.49 & 60.25 & 61.63 & 97.44 & 106.79 & 91.87 \\
\hline Glutamic acid & 46.71 & 48.16 & 41.53 & 56.71 & 76.12 & 76.37 \\
\hline Glycine & 1.00 & 1.03 & 1.78 & 2.39 & 2.48 & 2.06 \\
\hline Histidine $e^{\text {es }}$ & 6.61 & 8.14 & 7.09 & 12.91 & 8.15 & 9.24 \\
\hline Isoleucine $^{\mathrm{es}}$ & 9.01 & 9.51 & 11.73 & 16.30 & 12.01 & 10.52 \\
\hline Leucine $^{\mathrm{es}}$ & 4.22 & 5.80 & 3.25 & 4.81 & 5.07 & 6.20 \\
\hline Lysine $e^{\text {es }}$ & 7.61 & 5.55 & 11.05 & 19.67 & 17.39 & 14.59 \\
\hline Methionine $e^{\text {es }}$ & 2.70 & 4.33 & 4.77 & 8.17 & 9.68 & 7.42 \\
\hline Phenylalanine $e^{\text {es }}$ & 6.05 & 8.00 & 4.94 & 8.47 & 12.82 & 14.28 \\
\hline Proline & 6.02 & 35.10 & 6.38 & 11.47 & 8.65 & 12.85 \\
\hline Serine & 7.37 & 9.62 & 8.43 & 11.99 & 21.39 & 22.32 \\
\hline Threonine $^{\text {es }}$ & 8.77 & 8.56 & 7.61 & 7.53 & 15.94 & 16.85 \\
\hline Tyrosine & 16.67 & 15.49 & 16.93 & 21.93 & 22.80 & 16.83 \\
\hline Valine $e^{\text {es }}$ & 19.43 & 19.18 & 26.35 & 35.05 & 34.94 & 28.34 \\
\hline $\mathrm{AAS}^{\mathrm{es}}$ & 64.40 & 69.07 & 76.79 & 112.91 & 116.00 & 107.44 \\
\hline Total AAS & 312.73 & 445.64 & 427.96 & 689.81 & 636.99 & 712.65 \\
\hline
\end{tabular}

es essential amino acids.

Asn formed the highest portion on total amounts of free AAS in control and drought stressed tubers (Table 4), followed by glutamine (gln) and glutamic acid (glu), as a precursor for the synthesis of proline, a protectant against dehydration damage (Heldt, 2003). In tubers of St 89403, the last three AAS plus aspartic acid (asp) accounted on average for 63.6 (control) and $66.0 \%$ (drought stressed) on total AAS. In St 3792, the latter reached a portion of 69.7 and $71.7 \%$ and in cv. Agave, they accounted for 68.0 and $72.6 \%$ of total AAS. The amino acid contents of the present study were in a good agreement with those of other reports (Davies, 1977; Synge, 1977), and also the prominence of asn, gln, glu and asp concurred with published results (Galdón et al., 2010). Moreover it should be mentioned, that total amounts of these four AAS were higher in drought stressed tubers than in control tubers of all three genotypes, i.e. they were enhanced on average by 47.7\% (St 89403), 66.0\% (St 3792) and 19.4\% (cv. Agave), respectively.

In addition, it should be mentioned that the highest concentration of essential AAS was found in control tubers of cv. Agave, followed by drought stressed tubers of St 3792 (Table 4). St 3792, again, showed a clear enhancement of essential AAS $(+47.0 \%)$ by drought stress, a tendency that was observed less for the other genotypes. Amino acids are basic elements for the protein biosynthesis. Moreover, they are involved in metabolic reactions and serve as synaptic transmitter (Fonnum, 1984; Millward, 1999; Oldendorf, 1971; Hawkins et al., 2006). Apart from their 
health value, most amino acids have taste qualities and directly contribute to the flavour of foods, above all glutamic acid is known for its flavour enhancing capacity (Kemp \& Birch, 1992; Solms, 1969). It was important therefore to find out that drought stress had no negative effect on the level of free AAS comprising essential amino acids. On the contrary, many of the 18 AAS tested in this work were induced by drought stress, a fact which can be seen as an advantage with respect to adaptive responses and tuber quality including the health value. It is argued that changes in all these metabolites under drought stress conditions are associated with protecting cellular function and can be seen as a part of the adaptive response of plants to survive (Seki et al., 2007).

\subsection{Effect of Wounding Stress on Soluble Proteins}

In control tubers of all genotypes, the amounts of soluble proteins were higher $24 \mathrm{~h}$ after wounding, a tendency observed in both test years (Table 2). The differences in proteins due to wounding were statistically not significant in 2010, but they were significant in $2011(\mathrm{P}<0.01)$. The changes in soluble protein contents caused by wounding stress concurred with other reports (Mehta et al., 1991; Wegener \& Jansen, 2010). Although, within tubers imposed to drought stress during growth the effect of wounding stress was generally less evident. Only St 3792 showed a significant increase $(\mathrm{P}<0.05)$ in proteins after wounding of its drought stressed tubers. In this case, the enhancement of proteins by wounding was additive to those generated by drought stress. Furthermore, it should be mentioned that the increase in proteins after wounding was smaller on average, e.g. $+7.5 \%$ in 2010 and $+7.4 \%$ in 2011, than those associated with drought stress, e.g. $+59.6 \%$ in 2010 and $+37.3 \%$ in 2011 . With it, drought stress exhibited a stronger inducing effect on the protein levels than wounding stress had (Table 2). It seems thus that the tuber proteins are more important for drought stress responses than for wound stress responses of tubers, where plant phenols play a decisive role (Lulai \& Corsini, 1998). As mentioned already, the tuber protein patatin was down regulated after wounding (Logemann et al., 1988). It was not surprising therefore, that soluble proteins consisting to a high portion of the glycoprotein patatin were found to be less strongly affected by wounding stress.

\subsection{Correlations Between Parameters}

Significant correlations were discovered between phenols and proteins measured both in fresh and wounded control and drought stressed tubers grown in 2010 and 2011, and between the two test years for phenols and proteins (Table 5). Significant correlations for the last two parameters could also be detected between control and drought stressed tubers as well as between fresh and wounded tubers, in each year (Table 6). Moreover, significant correlations $(\mathrm{P}<0.01$, all $)$ were found for free amino acids between control and drought stressed tubers of the three genotypes St $89403(r=0.96)$, St $3792(r=0.99)$ and cv. Agave $(r=0.98)$.

\section{Conclusions}

The results revealed significant genotypic differences in the phenol and protein content and that drought stress leads to significantly higher level of soluble protein and lipid acyl hydrolase activity. Also the total amount of free amino acids, above all proline and asparagine was higher in drought stressed tubers than in control tubers. With it, the results highlight the role of proteins including lipid acyl hydrolases and free amino acids in adaptive responses of potato to drought stress. Wounding stress, on the other side, caused a significant increase of phenols in cv. Agave, a tendency which was less prominent in purple breeding clones that in general had higher phenol contents. Also proteins were enhanced after wounding, however this was less evident than it was found with drought stress. In summary, the results show that each component studied in this work fulfils its specific task within a complex network of tissue responses upon various types of environmental stress.

The fact that the amounts of phytochemicals like soluble phenols, proteins and free AAS including essential amino acids were not considerably reduced by drought stress is another important finding, above all with regard to the quality, nutritional and health value as well as resistance of potatoes grown under conditions of climate changes often associated with water scarcity. On the contrary, total amounts of free AAS and soluble proteins including the lipid acyl hydrolases associated with the glycoprotein patatin were increased by drought stress, a fact that can be seen as an advantage with regard to adaptive responses and tuber quality including the health value. 
Table 5. Correlations between proteins and phenols measured in 2010 and 2011, and correlations between the two test years for both parameters

\begin{tabular}{|c|c|c|c|c|c|}
\hline \multicolumn{2}{|c|}{ Correlation between } & \multicolumn{2}{|c|}{ Control } & \multicolumn{2}{|c|}{ Drought stress } \\
\hline & & Fresh & Wounded & Fresh & Wounded \\
\hline \multicolumn{6}{|c|}{ Proteins and phenols } \\
\hline \multicolumn{2}{|l|}{2010} & 0.86 & 0.81 & $0.50^{\mathrm{ns}}$ & 0.61 \\
\hline \multicolumn{2}{|l|}{2011} & 0.84 & 0.87 & 0.67 & 0.62 \\
\hline \multicolumn{6}{|c|}{2010 and 2011} \\
\hline \multicolumn{2}{|l|}{ Proteins } & 0.93 & 0.91 & 0.92 & 0.94 \\
\hline \multicolumn{2}{|l|}{ Phenols } & 0.98 & 0.93 & 0.95 & 0.89 \\
\hline \multicolumn{6}{|c|}{$\begin{array}{l}\text { The correlation coefficients that are not marked are statistically significant at } P \leq 0.05 \text {; ns, statistically } n \\
\text { significant }(P \geq 0.05) \text {. }\end{array}$} \\
\hline \multicolumn{6}{|c|}{$\begin{array}{l}\text { Table 6. Correlations between control and drought stressed tubers, and correlations between fresh and wound } \\
\text { tubers for phenols and proteins }\end{array}$} \\
\hline \multirow{3}{*}{ Parameters } & \multirow{3}{*}{ Year } & \multirow{2}{*}{\multicolumn{2}{|c|}{$\begin{array}{l}\text { Correlation between } \\
\text { control and drought stress }\end{array}$}} & \multirow{2}{*}{\multicolumn{2}{|c|}{$\begin{array}{l}\text { Correlation between } \\
\text { fresh and wounded tissue }\end{array}$}} \\
\hline & & & & & \\
\hline & & Fresh & Wounded & Control & Drought stress \\
\hline \multirow[t]{2}{*}{ Phenols } & 2010 & 0.96 & 0.92 & 0.97 & 0.98 \\
\hline & 2011 & 0.99 & 0.98 & 0.99 & 0.99 \\
\hline \multirow[t]{2}{*}{ Proteins } & 2010 & 0.78 & 0.76 & 0.97 & 0.98 \\
\hline & 2011 & 0.96 & 0.93 & 0.99 & 0.99 \\
\hline
\end{tabular}

The correlation coefficients are all statistically significant at $\mathrm{P} \leq 0.05$.

\section{Acknowledgements}

I. Schollenberg is thanked for excellent technical assistance.

\section{References}

Ali, G. M., \& Komatsu, S. (2006). Proteomic analysis of rice leaf sheath during drought stress. Journal of Proteome Research, 5, 396-403. http://dx.doi.org/10.1021/pr050291g

Anderson, C., Pinsirodom, P., \& Parkin, K. L. (2002). Hydrolytic selectivity of patatin (Lipid acyl hydrolase) from potato (Solanum tuberosum L.) tubers towards various lipids. Journal of Food Biochemistry, 26, 63-74. http://dx.doi.org/10.1111/j.1745-4514.2002.tb00050.x

Andrews, D. L., Beames, B., Summers, M. D., \& Park, W. D. (1988). Characterization of the lipid acyl hydrolase activity of the major potato (Solanum tuberosum L.) tuber protein, patatin, by cloning and abundant expression in a baculovirus vector. Biochemical Journal, 252, 199-206.

Anonymus. (2005). Water scarcity - International Decade for Action Water for Life 2005-2015. United Nations, Department for Economics and Social Affairs (UNDESA), 2005. Retrieved from http://www.un.org/waterforlifedecade/scarcity. shtml

Bárta, J., Bártová, V., Zdráhal, Z., \& Sedo, O. (2012). Cultivar variability of patatin biochemical characteristics: Table versus processing potatoes (Solanum tuberosum L.). Journal of Agricultural and Food Chemistry, 60, 4369-4378. http://dx.doi.org/10.1021/jf3003448

Bohac, J. R. (1991). A modified method to purify patatin from potato tubers. Journal of Agricultural and Food Chemistry, 39, 1411-1415. http://dx.doi.org/10.1021/jf00008a011 
Brown, C. R., Wrolstad, R., Durst, R., Yang, C. P., \& Clevidence, B. (2003). Breeding studies in potatoes containing high concentrations of anthocyanins. American Journal of Potato Research, 80, 241-250. http://dx.doi.org/10.1007/BF02855360

Buckenhüskes, H. J. (2005). Nutritionally relevant aspects of potatoes and potato constituents. In A. J. Haverkort \& P. C. Struik (Eds.), Potato in Progress: Science Meets Practice (pp. 17-26). Wageningen Academic Publishers: The Netherlands.

Cahill, D. M., \& McComb, J. A. (1992). A comparison of changes in phenylalanine ammonia-layse activity, lignin and phenolic synthesis in the roots of Eucalyptus calophylla (field resistant) and E. marginata (susceptible) when infected with Phytophthora cinamomi. Physiological and Molecular Plant Pathology, 40, 315-332. http://dx.doi.org/10.1016/0885-5765 (92)90014-M

Cahskan, M. E., Onaran, H., \& Orioglu, H. (2010). Overview of the Turkish potato sector: Challenges, achievements and expectations. Potato Research, 4, 255-266. http://dx.doi.org/10.1007/s11540-010-9170-1

Cahskan, M. E., \& Struik, P. C. (2010). Preface to special issue. Selected Papers and Abstracts of Section Meeting Agro-Physiology; Nevsehir, Turkey. Potato Research, 4, 253.

Cohen, S. A., \& Michaud, D. P. (1993). Synthesis of a fluorescent derivatizing reagent, 6-aminoquinolyl-Nhydroxysuccinimidyl carbamate, and its application for the analysis of hydrolysate amino-acids via highperformance liquid chromatography. Analytical Biochemistry, 211, 279-287. http://dx.doi.org/10.1006/abio.1993.1270

Creelman, R. A., \& Mullet, J. E. (1997). Biosynthesis and action of jasmonates in plants. Annual Review of Plant Physiology and Molecular Plant Pathology, 48, 355-381. http://dx.doi.org/10.1146/annurev.arplant.48.1.355

Crozier, A., Jaganath, I. B., \& Clifford, M. N. (2006). Phenols, Polyphenols and Tannins: An Overview. In A. Crozier, M. N. Clifford \& H. Ashihara (Eds.), Plant Secondary Metabolites (pp. 1-24). Oxford: Blackwall Publishing Ltd. http://dx.doi.org/10.1002/9780470988558.ch1

Davies, A. M. C. (1977). The free amino-acids of tubers of potato varieties grown in England and Ireland. Potato Research, 20, 9-21. http://dx.doi.org/10.1007/BF02362297

De Romana, G. L., Maclean W. C., Placko, R. P., \& Graham, G. G. (1981). Fasting and postprandial plasma-free amino acids of infants and children consuming exclusively potato protein. The Journal of Nutrition, 111, 1766-1771. Retrieved from http://intl-jn.nutrition.org

Desborough, S. L., Liener, I. E., \& Lulai, E. C. (1981). The nutritional quality of potato tuber protein from intraspecific hybrids. Qualitas-Plantarum-Plant Foods for Human Nutrition, 31, 11-20. http://dx.doi.org/10.1007/BF01093884

De Souza Candido, E., Pinto, M. F. S., Pelegrini, P. B., Lima, T. B., Silva, O. N., Pogue, R., Grossi-deSá, M., \& Franco, O. L. (2011). Plant storage protein with antimicrobial activity: Novel insight into plant defence mechanisms. The FASEB Journal, 25, 3290-3305. http://dx.doi.org/10.1096/fj.11-184291

Dixon, R. A., \& Paiva, N. L. (1995). Stress-induced phenylpropanoid metabolism. The Plant Cell, 7, 1085-1097. http://dx.doi.org/10.1105/tpc.7.7.1085

Espelie, K. E., Franceschi, V. R., \& Kolattukudy, P. E. (1986). Immonocytochemical localization and time course of appearance of an anionic peroxidase associated with suberization in wound-healing potato tuber tissue. Plant Physiology, 81, 487-492. http://dx.doi.org/10.1104/pp.81.2.487

Farhad, M. S., Babak, A. M., Reza, Z. M., Hassan, R. S. M., \& Afshin, T. (2011). Response of proline, soluble sugars, photosynthetic pigments and antioxidant enzymes in potato (Solanum tuberosum L.) to different irrigation regimes in greenhouse condition. Australien Journal of Crop Science, 5, 55-60.

Fonnum, F. (1984). Glutamate - a neurotransmitter in mammalian brain. Journal of Neurochemistry, 42, 1-11. http://dx.doi.org/10.1111/j.1471-4159.1984.tb09689.x

Friedman, M. (1997). Chemistry, biochemistry, and dietary role of potato phenols: A review. Journal of Agricultural and Food Chemistry, 45, 1523-1540. http://dx.doi.org/10.1021/j9960900s

Galau, G. A., Wang, H. Y. C., \& Hughes, D. W. (1993). Cotton Lea5 and Leal4 encode atypical late embryogenesis- abundant proteins. Plant Physiology, 101, 695-696. http://dx.doi.org/10.1104/pp.101.2.695 
Galdón, B. R., Mesa, D. R., Rodríguez, E. M. R., \& Romero, C. D. (2010). Amino acid content in traditional potato cultivars from the Canary Island. Journal of Food Composition and Analysis, 23, 148-153. http://dx.doi.org/10.1016/j.jfca.2009.08.009

Galliard, T. (1971). The enzymic deacylation of phospholipids and galactolipids in plants. Biochemical Journal, 121, 379-390. Retrieved from http://www.ncbi.nlm.nih.gov/pmc/articles/PMC1176584/pdf/biochemj00661

Ghanekar, A. S., Padwal-Desai, S. R., \& Nadkarni, G. B. (1984). The involvement of phenolics and phytoalexins in resistance of potato to soft rot. Potato Research, 27, 189-199. http://dx.doi.org/10.1007/BF02357464

Ghorbanli, M., Gafarabad, M., Amirkian, T., \& Allahverdi, B. (2011). Investigation of proline, total protein, chlorophyll, ascobate and dehydroascorbate under drought stress in Akria and Mobil tomato cultivars. Iranian Journal of Plant Physiology, 3, 651-658.

Gigon, A., Matos, A. R., Laffray, D., Zuily-Fodil, Y., \& Pham-Thi, A. T. (2004). Effect of drought stress on lipid metabolism in the leaves of Arabidopsis thaliana (Ecotype Columbia). Annals of Botany, 94, 345-351. http://dx.doi.org/10.1093/aob/mch150

Good, A. G., \& Zaplachinski, S. T. (1994). The effects of drought stress on free amino acid accumulation and protein synthesis in Brassica napus. Physiologica Plantarum, 90, 9-14. http://dx.doi.org/10.1111/j.1399-3054.1994.tb02185.x

Goyal, K., Walton, L. J., \& Tunnacliffe, A. (2005). LEA proteins prevent protein aggregation due to water stress. Biochemistry Journal, 388, 151-157. http://dx.doi.org/10.1042/BJ20041931

Grace, S. C. (2005). Phenolics as antioxidants. In N. Smirnoff (Ed.), Antioxidants and Reactive Oxygen Species in Plants. (pp. 141-168). Oxford: Blackwall Publishing Ltd.

Hand, S. C., Menze, M. A., Toner, M., Boswell, L., \& Moore, D. (2011). LEA proteins during water stress: Not just for plants anymore. Annual Review of Physiology, 73, 115-134. http://dx.doi.org/10.1146/annurev-physiol-012110-142203

Hasson E. P., \& Laties, G. G. (1976). Separation and Characterization of potato lipid acyl hadrolases. Plant Physiology, 57, 142-147. http://dx.doi.org/10.1104/pp.57.2.142

Hawkins, R. A., O'Kane, R. L., Simpson, I. A., \& Vina, J. R. (2006). Structure of the blood brain-brain barrier and its role in the transport of amino acids. The Journal of Nutrition, 136, 218-226. Retrieved from http://jn.nutrition.org/content/136/1/2185.full.pdf $+h t m l$

Heldt, H. W. (2003). Biosynthesis of proline and arginine. H. W. Heldt (Ed.) Biochemistry (pp. 303-304). Heidelberg: Spectrum Academic Publishing.

Hernandez-Orte, P., Ibarz, M. J., Cacho, J., \& Ferreira, V. (2003). Amino acid determination in grape juices and wines by HPLC using a modification of the 6-aminoquinolyl-N-hydroxysuccinimidyl carbamate (AQC) method. Chromatographia, 58, 29-35. http://dx.doi.org/10.1365/s10337-003-0002-1

Hong-Bo, S., Zong-Suo, L., \& Ming-An, S. (2005). LEA proteins in higher plants: Structure, function, gene expression and regulation. Colloids and Surfaces B. Biointerphases, 45, 131-135.

Jansen, G., Flamme, W., Schüler, K., \& Vandrey, M. (2001). Tuber and starch quality of wild and cultivated potato species and cultivars. Potato Research, 44, 137-146. http://dx.doi.org/10.1007/BF02410100

John, D. B. A., Kumar, P. B. J. R., Gracelin, D. H. S., \& Jency, S. S. (2011). Drought stress and its impact on protein in three species of Vitex. Journal of Stress Physiology and Biochemistry, 7, 152-158. Retrieved from http://www.jspb.ru/issues/2011/N3/JSPB_2011_3_152-158.pdf

Kapoor, A. C., Desborogh, S. L., \& Li, P. H. (1975). Potato protein and their nutritional quality. Potato Research, 18, 469-478. http://dx.doi.org/10.1007/BF02361913

Kemp, S. E., \& Birch, G. G. (1992). An intensity/time study of the taste of amino acids. Chemical Senses, 17, 151-168. http://dx.doi.org/10.1093/chemse/17.2.151

Liu, Y. W., Han, C. H., Lee, M. H., Hsu F. L., \& Hou, W. C. (2003). Patatin, the tuber storage protein of potato (Solanum tuberosum L.) exhibits antioxidant activity in vitro. Journal of Agricultural and Food Chemistry, 51, 4389-4393. http://dx.doi.org/10.1021/jf030016j

Logemann, J., Mayer, J. E., Schall, J., \& Willmitzer, L. (1988). Differential expression of genes in potato tubers after wounding. Proceedings of the National Academy of Science USA, 85, 1136-1140. http://dx.doi.org/10.1073/pnas.85.4.1136 
Lulai, E. C., \& Corsini, D. L. (1998). Differential deposition of suberin phenolic and aliphatic domains and their role in resistance to infection during potato tuber (Solanum tuberosum L.) wound healing. Physiological and Molecular Plant Pathology, 53, 209-222. http://dx.doi.org/10.1006/pmpp.1998.0179

Lyon, G. D., \& McGill, F. M. (1988). Inhibition of growth of Erwinia carotovora in vitro by phenolics. Potato Research, 31, 461-467. http://dx.doi.org/10.1007/BF02357883

Macrae, A. R., Visicchio, J. E., \& Lanot, A. (1998). Application of lipid acyl hydrolase for the synthesis of monoglycerols. Journal of the American Oil Chemist's Society, 75, 1489-1494. http://dx.doi.org/10.1007/s11746-998-0083-y

Mafakheri, A., Siosemardeh, A., Bahramnejad, B., Struik, P. C., \& Sohrabi, Y. (2011). Effect of drought stress and subsequent recovery on protein, carbohydrate contents, catalase and peroxidase activities in three chickpea (Cicer arietinum) cultivars. Australien Journal of Crop Science, 5, 1255-1260.

Martinelli, T., Whittaker, A., Bochicchio, A., Vazzana, C., Suzuki, A., \& Masclaux-Daubresse, C. (2007). Amino acid pattern and glutamate metabolism during dehydration stress in the 'resurrection' plant Sporobolus stapfianus: A comparison between desiccation-sensitive and desiccation-tolerant leaves. Journal of Experimental Botany, 58, 3037-3046. http://dx.doi.org/10.1093/jxb/erm247

Mehta, R. A., Parsons, B. L., Mehta, A. M., Nakhasi, H. L., \& Mattoo, A. K. (1991). Differential protein metabolism and gene expression in tomato fruit during wounding stress. Plant and Cell Physiology, 32, 1057-1065. Retrieved from http://pcp.oxfordjournals.org/content/32/7/1057.full.pdf

Meier, U. (1997). Growth stages of mono- and dicotyledonous plants. In U. Meier (Ed.). BBC-Monograph (p. 48). Berlin: Blackwall Publishing Ltd.

Millward, D. J. (1999). The nutritional value of plant-based diets in relation to human amino acid and protein

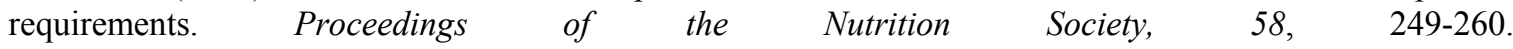
http://dx.doi.org/10.1017/S0029665199000348

Mohammadkhani, N., \& Heidari, R. (2008). Effect of drought stress on soluble proteins in two maize varieties. Turkish Journal of Biology, 32, 2008.

Mohammadkhani, N., \& Heidari, R. (2008). Drought-induced accumulation of soluble sugars and proline in two maize varieties. World Applied Sciences Journal, 3, 448-453.

Moreau, R. A., \& Nagahashi, G. (1987). Glycoprotein nature of lipolytic acyl hydrolases in potato tubers and leaves. In D. California, P. K. Stumpf, J. B. Mudd \& W. D. Nes (Eds.). The Metabolism, Structure and Function of Plant Lipids (pp. 369-371) $7^{\text {th }}$ International Symposium on Plant Lipids, 1986, New York: Plenum Press,

Munawarti, A., Taryono, Semiarti, E., Holford, P., \& Sismindari. (2013). Tolerance of accessions of glagah (Saccharum spontaneum) to drought stress and their accumulation of proline. American Journal of Agricultural and Biological Science, 8, 1-11. http://dx.doi.org/10.3844/ajabssp.2013.1.11

Nicholson, R. L., \& Hammerschmidt, R. (1992). Phenolic compounds and their role in disease resistance. Annual Review of Phytopathology, 30, 369-389. http://dx.doi.org/10.1146/annurev.phyto.30.1.369

Noctor, G., \& Foyer, C. H. (1998). Ascorbate and glutathione: Keeping active oxygen under control. Annual Review of Plant Physiology and Plant Molecular Biology, 49, 249-279. http://dx.doi.org/10.1146/annurev.arplant.49.1.249

Oldendorf, W. H. (1971). Brain uptake of radiolabelet amino acids, amines and hexoses after arterial injection. American Journal of Physiology, 221, 1629-1639.

Passioura, J. (2007). The drought environment: physical, biological and agricultural perspectives. Journal of Experimental Botany, 58, 113-117. http://dx.doi.org/10.1093/jxb/erl212

Racusen, D. (1984). Lipid acyl hydrolase of patatin. Canadian Journal of Botany, 62, 1640-1644. http://dx.doi.org/10.1139/b84-220

Racusen, D., \& Foote, M. (1980). A major soluble glycoprotein of potato tubers. Journal of Food Biochemistry, 4, 43-52. http://dx.doi.org/10.1111/j.1745-4514.1980.tb00876.x

Schaller, F., Schaller, A., \& Stintzi A. (2005). Biosynthesis and Metabolism of Jasmonates. Journal of Plant Growth Regulation, 23, 179-199. http://dx.doi.org/10.1007/BF02637260 
Seki, M., Umezawa, T., Urano, K., \& Shinozaki, K. (2007). Regulatory metabolic networks in drought stress responses. Current Opinion in Plant Biology, 10, 296-302. http://dx.doi.org/10.1016/j.pbi.2007.04.014

Solms, J. (1969). Taste of amino acids, peptides and proteins. Journal of Agricultural and Food Chemistry, 17, 686-688. http://dx.doi.org/10.1021/jf60164a016

Strickland, J. A., Orr, G. L., \& Walsh, T. A. (1995). Inhibition of Diabrotica larval growth by patatin, the lipid acyl hydrolase from potato tubers. Plant Physiology, 109, 667-674. Retrieved from http://www.plantphysiol.org/content/109/2/667.long

Synge, R. L. M. (1977). Free amino acids of potato tubers: A survey of published results set out according to potato variety. Potato Research, 20, 1-8. http://dx.doi.org/10.1007/BF02362296

Vance, C. P., Kirk, T. K., \& Sherwood, R. T. (1980). Lignification as a mechanism of disease resistance. Annual Review of Phytopathology, 18, 259-288. http://dx.doi.org/10.1146/annurev.py.18.090180.001355

Vayda, M. E., \& Schaeffer, H. J. (1988). Hypoxic stress inhibits the appearance of wound-response proteins in potato tubers. Plant Physiology, 88, 805-809. http://dx.doi.org/10.1104/pp.88.3.805

Weber, J., Olsen, O., Wegener, C. B., \& von Wettstein, D. (1996). Digalacturonates from pectin degradation induce tissue responses against potato soft rot. Physiological and Molecular Plant Pathology, 48, 389-401. http://dx.doi.org/10.1006/pmpp.1996.0031

Wegener, C. B., \& Jansen, G. (2010). Antioxidant capacity in cultivated and wild Solanum species: The effect of wound stress. Food and Function, 1, 209-218. http://dx.doi.org/10.1039/c0fo00063a

Wegener, C. B., \& Jansen, G. (2013). Antioxidants in different potato genotypes: Effect of drought and wounding stress. Agriculture, 3, 131-146. http://dx.doi.org/10.3390/agriculture3010131

Yancey, P. (2001). Water stress, osmolytes and proteins. American Zoologist, 41, 699-709. http://dx.doi.org/10.1668/0003-1569(2001)041[0699:WSOAP]2.0.CO;2

Yang, F., \& Miao, L. F. (2010). Adaptive responses to progressive drought stress in two poplar species originating from different altitudes. Silva Fennica, 44, 23-37. http://dx.doi.org/10.14214/sf.160

\section{Copyrights}

Copyright for this article is retained by the author(s), with first publication rights granted to the journal.

This is an open-access article distributed under the terms and conditions of the Creative Commons Attribution license (http://creativecommons.org/licenses/by/3.0/). 